\title{
Geç Dönemde Hastanede Gelișen Pnömoni Etkenlerinin Hızlı Moleküler Biyolojik Yöntemlerle Saptanması
}

\section{The Detection of Causative Agents With Rapid Molecular Biological Medhods in Late Onset Hospital Acquired Pneumonia}

\author{
Ahmet UYSAL ${ }^{1}(\mathrm{ID})$, Mehmet Sezai TAȘBAKAN²(ID), Șöhret AYDEMiR ${ }^{3}$ (IDD), Hüsnü PULLUKCุU (ID), \\ Feriha ÇiLLi ${ }^{3}(\mathrm{IID})$, Feza BACAKOG̃LU²(ID)
}

\footnotetext{
${ }^{1}$ Trakya Üniversitesi Tıp Fakültesi Hastanesi, Gög̈üs Hastalıkları Klinig̃i, Edirne, Türkiye

${ }^{2}$ Ege Üniversitesi Tıp Fakültesi, Gög̃üs Hastalıkları Anabilim Dalı, İzmir, Türkiye

${ }^{3}$ Ege Üniversitesi Tıp Fakültesi, Tıbbi Mikrobiyoloji Anabilim Dalı, İzmir, Türkiye

${ }^{4}$ Ege Üniversitesi Tıp Fakültesi, İnfeksiyon Hastalıkları ve Klinik Mikrobiyoloji Anabilim Dalı, İzmir, Türkiye
}

Makale atıfı: Uysal A, Taşbakan MS, Aydemir ş, Pullukçu H, Çilli F, Bacakoğlu F. Geç dönemde hastanede gelişen pnömoni etkenlerinin hızlı moleküler biyolojik yöntemlerle saptanması. FLORA 2021;26(1):78-87.

\section{ÖZ}

Giriş: Hastaneye yatışı takip eden beşinci günden sonra ortaya çıkan geç dönemde hastanede gelişen pnömonilere (HGP) genellikle çok ilaca dirençli bakteriler neden olmaktadır. Etkenlerin geç saptanması, uygun antibiyotiğin zamanında başlanamaması HGP prognozunu olumsuz olarak etkilemektedir. Son yıllarda infeksiyon etkeni mikroorganizmaların hızlı moleküler yöntemlerle kısa sürede izole edilmesi, tedavinin daha erken ve etkin olarak başlanmasını sağlamaktadır. Bu çalışmada, HGP'de etkenlerin hızlı moleküler yöntemlerle saptanması ve sonuçların konvansiyonel yöntemlerle karşılaştırılması amaçlanmıştır.

Materyal ve Metod: Ocak 2014 ile Ocak 2016 tarihleri arasında göğüs hastalıkları ile anestezi ve reanimasyon yoğun bakım ünitelerinde izlenen ve 2005 yılında yayımlanan ATS-IDSA kriterlerine göre HGP tanısı alan altmış iki hasta çalışmaya alınmıştır. HGP tanısı düşünüldüğü anda hastalardan bronkoskopik (BAL, BASP) ve nonbronkoskopik (mini-BAL) yöntemlerle alt solunum yolu örnekleri alınmıştır. Alınan örnekler hem konvansiyonel yöntemler ve hem de hızlı moleküler yöntemlerle bakteriyolojik etkenler açısından incelenmiştir.

Bulgular: Hastanede gelişen pnömoni tanısı alan altmış iki hasta (kırk iki erkek, yaş ortalaması $69.7 \pm 15.6$ ) alınmıştır. Hastaların \%95.2'sinde ek hastalık olup, otuz üç hastaya invaziv mekanik ventilasyon (iMV), 28 hastaya iMV + non-invaziv mekanik ventilasyon (Niv) uygulanmıştır. Konvansiyonel yöntem ile altmış iki hastanın kırkında (\%64.5) bakteriyel etken saptanırken, polimeraz zincir reaksiyon (PZR) ile altmış iki hastanın elli yedisinde (\%91.9) bakteriyel etken izole edilmiştir. Etken saptanması açısından konvansiyonel yöntem ile PZR yönteminin birbiriyle uyumlu olduğu gözlenmiştir (kappa: 0.797). Ayrıca, PZR ile etken saptanma oranının anlamlı olarak yüksek olduğu görülmüştür $(p=0.0004)$. Her iki yöntem ile en sık Acinetobacter baumannii saptanmıştır. İlemde altmış iki hastanın kırk beşinde (\%72.6) mortalite izlenmiştir.

Sonuç: Geç dönemde ortaya çıkan HGP etkenlerinin saptanmasında konvansiyonel yöntemler ile PZR arasında uyumun iyi olduğu ve PZR ile daha fazla hastada etken saptanabileceği bu çalısmada gösterilmiştir.

Anahtar Kelimeler: Hastanede gelişen pnömoni; Bakteriyel etkenler; Hızlı moleküler yöntemler; Polimeraz zincir reaksiyonu (PZR) 


\title{
ABSTRACT \\ The Detection of Causative Agents With Rapid Molecular Biological Medhods in Late Onset Hospital Acquired Pneumonia
}

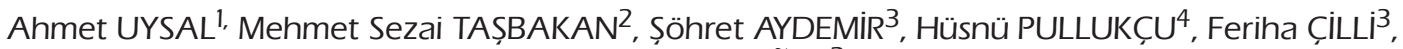 \\ Feza BACAKOG̃LU²
}

\footnotetext{
${ }^{1}$ Clinic of Chest Diseases, Trakya University, Faculty of Medicine Hospital, Edirne, Turkey

${ }^{2}$ Department of Chest Diseases, Ege University Faculty of Medicine, İzmir, Turkey

${ }^{3}$ Department of Medical Microbiology, Ege University Faculty of Medicine, İzmir, Turkey

${ }^{4}$ Department of Infectious Diseases and Clinic Microbiology, Ege University Faculty of Medicine, İzmir, Turkey
}

Introduction: Late-onset hospital-acquired pneumonia (HAP) developing after the fifth day following admission to the hospital is usually caused by multi-drug resistant bacteria. Late detection of the agents and failure in starting the appropriate antibiotic treatment timely negatively affect HAP prognosis. Isolating infectious microorganisms in a short time by fast molecular methods in the last years has ensured that treatment can be started earlier and more effectively, which is thought to affect prognosis positively. In this study, it was aimed to determine the factors in HAP with rapid molecular methods and to compare the results with conventional methods.

Materials and Methods: A total of 62 patients diagnosed with HAP according to the criteria of ATS/IDSA published in 2005 and followed-up in the intensive care units of Anesthesia and Reanimation Department and Chest Disease Departments between January 2014 and January 2016 were included into the study. Lower respiratory tract samples were obtained from patients after HAP diagnosis with bronchoscopic (bronchoalveolar lavage (BAL), bronchoscopic aspiration (BASP) and non-bronchoscopic (mini-BAL) methods. The samples were examined in terms of bacteriological agents with conventional methods and fast molecular methods.

Results: Sixty-two patients (42 males, mean age: $69.7 \pm 15.6)$ diagnosed with hospital-acquired pneumonia were included. Ninety-five point two percent of the patients had a comorbid disease. Invasive mechanical ventilation (IMV) was applied to 33 patients and non-invasive mechanical ventilation (NIV) was applied to 28 patients. In a total of 62 patients conventional methods and polymerase chain reaction $(P C R)$ were used to detected in 40 (64.5\%) and in 57 (91.9\%) patients, respectively. It was observed that the conventional method and the PCR method were compatible with each other in terms of detecting the agent (kappa: 0.797). Besides, PCR was found to have a significantly higher rate of agent detection $(p=0.0004)$. Acinetobacter baumannii was detected most frequently with both methods. In the follow-up, mortality was observed in 45 (72.6\%) of the 62 patients.

Conclusion: As a result, it was shown in this study that there is a good agreement between conventional methods and $P C R$ in the detection of late-onset HAP agents and that agents can be detected by PCR in more patients.

Key Words: Hospital-acquired pneumonia; Bacterial agents; Rapid molecular methods; Polymerase chain reaction (PCR)

\section{GiRiș}

Hastanede Gelisen Pnömoni (HGP); hastaneye yatıștan 48 saat sonra gelișen ve hastanın yatıșında inkübasyon döneminde olmadığı bilinen pnömoni olguları ile, hastaneden taburcu olduktan sonraki 48 saat içinde ortaya çkan pnömoni olarak tanımlanır ${ }^{[1]}$. HGP, tüm hastane kökenli infeksiyonlar içerisinde \%22 oranında görülmekte olup hastanede gelișen infeksiyonlar arasında en s1k mortaliteyi olusturmaktadır ${ }^{[2]}$. Gelișme süresine göre HGP, erken ve gec dönem HGP olarak ikiye ayrlır. Gec dönemde hastanede gelisen pnömoni, hastaneye yatıstan sonra beșinci ve daha sonraki günlerde gelișen pnömonidir. Gec dönemde HGP'lerde, Acinetobacter baumannii,
Pseudomonas aeruginosa, Klebsiella pneumoniae, Escherichia coli ve diğer Enterobacteriaceae, Stenotrophomonas maltophilia, Metisiline dirençli Staphylococcus aureus (MRSA) gibi dirençli bakteriler etyolojide yer almaktadir ${ }^{[1]}$. Otuz günlük mortalite oranı HGP için \%29.9 iken, erken bașlangıçı HGP için \%19.2, geç dönemde HGP için mortalite oranı \%31.4'e yükselmektedir ${ }^{[3]}$.

Hastanede gelișen pnömoni tanısını koymak zor olduğu gibi etkenlerin de saptanması her zaman mümkün olamamaktadır. Tanı zorluğu, gereksiz antibiyotik kullanımina ve bunun sonucunda da antibiyotiklere dirençli bakteri infeksiyonu riski, toksisite ve tedavi maliyetinde artıșa neden olmaktadır $^{[1]}$. 
Hastanede gelișen pnömoni veya ventilatör ilișkili pnömoni (VIP) tanısını koymada altın standart bir yöntem yoktur. Tanı genellikle klinik olarak süphelenme sonucunda koyulmaktadır. Yapilan calıșmalarda klinik olarak ViP tanısı konulan hastaların \%50'sinde ViP bulunmazken, buna karșin ViP'i olan hastaların yaklassı olarak $1 / 3$ 'üne tanı konulamadığı görülmüștürr ${ }^{[4]}$. Özellikle VIP düșünülen hastalarda klinik pulmoner infeksiyon skorunun (CPIS) kullanımı tanı koymada özgülliuğü ve duyarllığı düșük olsa da tedavi izleminde ve tedaviyi sonlandırmada yol gösterici olmaktadır ${ }^{[1]}$.

Son yllarda bakteriyel etkenlerin 2-6 saat içinde antibiyotik duyarlllik paternleri ile birlikte belirlenmesine olanak sağlayan hızlı moleküler yöntemlerin kullanımları gündeme gelmistirir ${ }^{[5]}$. Ancak, bu moleküler yöntemlerin bronkoalveolar lavaj (BAL) sivisinda ve trakeal aspirasyon örneklerinde kullanımı ile ilgili henüz yeterli kanıt bulunmamaktadır. Son yıllarda BAL sivisı ve kanda bazı biyobelirteçlerin tanısal değerleri araștırılmaktır. Özellikle prokalsitoninin ise ViP tanisı alan hastaların antibiyotik tedavi sürelerinin belirlenmesinde kullanılabileceği ileri sürülmüștür ${ }^{[6]}$.

Geç dönemde ortaya çkan HGP'nin mortalitesinin ve tedavi maliyetinin yüksek olması nedeniyle etiyolojide yer alan etkenlerin saptanmasına yönelik yöntemlerin belirlenmesi büyük önem tașımaktadır. HGP etkenlerinin hızlı moleküler yöntemlerle saptanması iletkene yönelik tedavinin kısa sürede bașlanabilmesi ve olumlu klinik yanitın erken alınması mümkün olacaktır. Bu calıșmada, gec dönemde ortaya cıkan HGP etkenlerinin saptanmasında hızlı moleküler yöntemler ile konvansiyonel yöntemlerin uyumunun belirlenmesi amaçlanmıstır.

\section{MATERYAL ve METOD}

Ocak 2014-Aralı 2016 tarihleri arasında göğuis hastalıkları ile anestezi ve reanimasyon yoğun bakım ünitesinde izlenen ve 2005 yılında yayımlanan ATS/IDSA kriterlerine göre HGP tanisı alan altmıs iki hasta calıșmaya alınmıștır.

\section{Çalıșmaya Alınma Ölçiitleri}

a. Hastaneye yatısından veya entübasyondan 48 saat sonra gelișen, akciğer grafisinde yeni ya da ilerleyici infiltrasyon saptanan hastalarda, $>38^{\circ} \mathrm{C}$ ates, lökositoz ( $>12000$ hücre $/ \mathrm{mm}^{3}$ ) ya da lökopeni $\left(<4000\right.$ hücre $\left./ \mathrm{mm}^{3}\right)$, pürülan sek- resyon, oksijenizasyonda azalma kriterlerinden iki veya daha fazlasının olmasi ${ }^{[7]}$,

b. 18 yașından büyük olmak,

c. Bilgilendirilmis gönülliu onam almak (Hasta veremiyorsa yakınından),

d. Hastadan alt solunum yolu örneği (BAL, mini-BAL) almaya engel bir durumun olmaması.

\section{Örneklerin Toplanması}

BAL ișleminde, entübasyon tüpü yoluyla fleksibl bronkoskop (Olympus CLE-10 USA) kullanilarak bronkoskopun aspirasyon kanalı yoluyla, $\% 0.9 \mathrm{NaCl} 20 \mathrm{~mL}$ fraksiyonlar halinde enjektörle verilmiș ve yine aynı enjektörle verilen sıvı aspire edilmistir. Verilen toplam 120-150 cc sivinın \%60'ın geri alınması hedeflenmistir.

Bronkoskopik aspirasyon (BASP) isleminde, entübasyon tüpü yoluyla fleksbıl bronkoskop (Olympus CLE-10 USA) kullanılarak; radyolojik bulgularına göre pnömoni düșünülen akciğer anatomik birimine bronkoskop ilerletilip, bu alana bronkoskop aracilyğ1 ile $50 \mathrm{~mL} \% 0.9 \mathrm{NaCl}$ verilmiș ve verilen sivı bronkoskopun aspirasyon sisteminden geri alınmıștır.

Mini-BAL ișleminde, lavaj kateteri (combicath TM; plastimed, Saint-Leu-La Forkt, Fransa) entübasyon tüpü yoluyla alt hava yollarına ilerletilmiștir. İlerletme ișlemi tamamlandıktan sonra kateter ucundaki koruyucu kllif çkarılip kateterin brons ağacı içerisinde biraz daha ilerlemesi sağlanmıștır. Son olarak 20 cc \%0.9 $\mathrm{NaCl}$ kateter yolu ile verilip tekrar ayn enjektör ile aspire edilmistir.

\section{Mikrobiyolojik İnceleme}

Alınan örnekler hem konvansiyonel yöntemlerle hem de hızlı moleküler yöntemlerle incelenmiștir. Konvansiyonel yöntemler için ayrilan örnekler aynı gün incelemeye alınırken; hızlı moleküler yöntemler için alınanlar ise toplu olarak çalıșlmak üzere çalıșma gününe kadar $-80^{\circ} \mathrm{C}$ 'de saklanmıstır. Konvansiyonel incelemede, kantitatif kültür yöntemleri kullanılıp BAL için $10^{4} \mathrm{CFU} / \mathrm{mL}$, BASP ve mini-BAL için $10^{5} \mathrm{CFU} / \mathrm{mL}$ üreme anlamlı olarak kabul edilmiștir. Bakteriyel etkenlerin identifikasyonu için Maldi-TOF MS (VITEK MS, BioMerieux, Fransa) ve antibiyotik duyarlll1k testleri için otomatik sistem (VIṪEK2, BioMerieux, Fransa) kullanılmıștır. 
Moleküler incelemede, dört temel bakteriyi (Staphylococcus aureus, Pseudomonas aeruginosa, Acinetobacter baumannii, Stenotrophmonas maltophilia) saptamak amaciyla Real Time polimeraz zincir reaksiyonu (PZR) kiti gelistirilmiștir. Her bir kökenden elde edilen DNA'lar 1/10 dilüsyonlar yapılarak PZR etkinlik değerleri ve ideal PZR sıcaklık döngü koșulları tespit edilmiștir (Tüm patojenler için PZR etkinlik değerleri E: 1.85-2.1 arasında bulunmustur). Belirtilen gen bölgeleri hedef alınarak primer probe setleri hazırlanmıstır.

Saklanan örneklerden $\left(-80^{\circ} \mathrm{C}\right.$ 'de $)$ "GenAll DNA/RNA Extraction Kit" (GenAll, Güney Kore) kullanılarak kit içeriğinde önerildiği sekilde DNA ekstraksiyonu gerçekleștirilmiștir. Elde edilen 200 $\mu \mathrm{L}$ nükleik asit solüsyonunun $5 \mu \mathrm{L}$ 'si amplifikasyona alınmıștır. Amplifikasyon için, 2 X Realtime Multiplex Mix with UDG (Genmark Sağllk Ürünleri, Türkiye) kullanılmıs, amplifikasyon, saptama ve veri analizi Realtime PZR cihazında (CFX96-IVD Biorad, ABD) calıșılmıștır.

Örnekte floresan sinyali alınmıs ise, internal kontrolde "melting peak" gözlenmiș ise ve ekstraksiyon ve amplifikasyon için pozitif kontroller pozitif, negatif kontroller negatif sonuçanmıs ise test sonucu pozitif kabul edilmiștir.

\section{İstatistiksel Analiz}

HGP saptamak üzere PZR yöntemi ve konvansiyonel yöntemin karssılaștırılması amacıyla yapilan araștırmada sürekli verilerin analizinde normal dağılıma uygunluk Kolmogrov-Smirnov analizi ile incelenmiş normal dağılan veriler ortalama \pm standart sapma ile sunulmuștur. Sürekli değișkenlerin karșlaștırılmasında t testi, bağımlı gruplarda kategorik değiskenlerin karșılaștırılmasında ise Mcnemar testi kullanılmıștır. $\mathrm{p}<0.05$ düzeyi anlamlı kabul edilmiștir. İki yöntemin uyumu kappa testi ile değerlendirilmis, $\quad \mathrm{p}<0.05$ değeri istatistiksel olarak anlamlı kabul edilmiștir.

Araștırma etik ve bilimsel araștırma proje izinleri için Ege Üniversitesi Tip Fakültesi Etik Kurulundan 26.06.2014 tarih, 14-5.1/10 sayı ile onay alınmıstır.

\section{BULGULAR}

Calıșmamıza Göğüs Hastalıkları Anabilim Dalı kliniği ile Anestezi ve Reanimasyon Anabilim Dalı
Yoğun Bakım Ünitesi'nde takip edilen toplam 62 (42 erkek, ortalama yas $69.7 \pm 15.6$ ) hasta alınmıștır. Hastaların kırk altısı (\%74) göŏüus hastalıkları kliniğinde izlenirken, on altısı (\%26) anestezi ve reanimasyon kliniğinde izlenmiștir. Tablo 1 'de hastaların bașuru anındaki tanımlayıcı özellikleri yer almaktadır.

Hastaneye yatıșlarının 48. saatinden sonraki izleminde hastanede gelisen pnömoni tanısı alan hastalar calıșmaya alınmıștır. Hastanede gelișen pnömoni tanısı düșünüldüğü anda bakteriyolojik inceleme için elli bir hastadan mini-BAL, yedi hastadan BAL ve dört hastadan BASP alınmıstır.

Pnömoni tanı anındaki infeksiyon belirteçeri ile radyolojik bulgular Tablo 2'de belirtilmiștir.

Konvansiyonel yöntem ile altmıs iki hastanın kırkında (\%64.5), PZR ile altmıs iki hastanın elli yedisinde (\%91.9) bakteriyel etken saptanmıstır. Etken saptama oranının PZR ile anlaml olarak yüksek olduğu görülmüștür ( $p<0.001$ ) (Șekil 1). Her iki yöntemle saptanan bakteriyel etkenler beraber değerlendirildiğinde, etken saptanması aç1sından konvansiyonel yöntem ile PZR yönteminin birbiri ile uyumlu olduğu gözlenmiștir (kappa: 0.797). PZR yönteminin konvansiyonel yönteme göre duyarlllı̆̆1 \%97.5 iken özgüllüğü \%18 olarak bulunmuștur. Pozitif prediktif değer ise \%68.4 olarak hesaplanmıstır.

Hastalardan alınan solunum örneklerinin konvansiyonel yöntemle incelenmesi sonucunda otuz üc (\%53.2) hastada tek bakteriyel etken izole edilirken, yedi (\%11.3) hastada birden fazla etken izole edilmiștir. Yirmi iki (\%35.5) hastada konvansiyonel yöntem ile etken saptanamamıștır. Konvansiyonel yöntem ile; yirmi dört hastada sadece $A$. baumannii, iki hastada $A$. baumannii ve $P$. aeruginosa, bir hastada $A$. baumannii ve $K$. pneumonia, bir hastada $A$. baumannii ve Corynebacterium striatum, altı hastada sadece $P$. aeruginosa, bir hastada $P$. aeruginosa ve $K$. pneumonia, bir hastada $P$. aeruginosa ve $C$. striatum, bir hastada $P$. aeruginosa ve $S$. maltophilia, bir hastada sadece $S$. maltophilia, bir hastada sadece $S$. aureus, bir hastada ise sadece K. pneumonia izole edilmiștir.

Solunum örneklerinin PZR ile değerlendirilmesi sonucunda otuz altı (\%58.1) hastada tek bakteri- 


\begin{tabular}{|c|c|}
\hline Yaş (ortalama $\pm \mathrm{sd}$ ) & $69.7 \pm 15.6$ \\
\hline Cinsiyet (K/E) & $20 / 42$ \\
\hline $\begin{array}{l}\text { Yatış tanıları }(\mathrm{n}, \%) \\
\text { Pnömoni } \\
\text { KOAH } \\
\text { PTE } \\
\text { OUAS } \\
\text { Diğer }\end{array}$ & $\begin{array}{l}42(67.8) \\
8(13) \\
1(1.6) \\
1(1.6) \\
10(16)\end{array}$ \\
\hline $\begin{array}{l}\text { Ek hastalıklar }(n, \%) \\
\text { KOAH } \\
\text { HT } \\
\text { DM } \\
\text { Santral sinir sistemi hastalıkları } \\
\text { Malignite } \\
\text { Diğer hastalıklar } \\
\text { Ek hastalığı olmayan }\end{array}$ & $\begin{array}{l}16(13.8) \\
16(13.8) \\
15(12.9) \\
14(12.0) \\
13(11.2) \\
39(33.6) \\
3(2.6)\end{array}$ \\
\hline $\begin{array}{l}\text { İmmün yetmezlik durumu }(n, \%) \\
\text { Yok } \\
\text { Var }\end{array}$ & $\begin{array}{l}51(82.3) \\
11(17.7)\end{array}$ \\
\hline $\begin{array}{l}\text { İmmünyetmezlik nedenleri }(\mathrm{n}, \%) \\
\text { Kortikosteroid kullanımı } \\
\text { Kemoterapi } \\
\text { Hematolojik malignite }\end{array}$ & $\begin{array}{l}5(46) \\
4(36) \\
2(18)\end{array}$ \\
\hline $\begin{array}{l}\text { Solunum yetmezliği tedavisi (n,\%) } \\
\text { iMV } \\
\text { iMV+NiV } \\
\text { Oksijen inhalasyonu }\end{array}$ & $\begin{array}{l}33(53) \\
28(45) \\
1(2)\end{array}$ \\
\hline Başvuru $\mathrm{PaO}_{2} / \mathrm{FiO}_{2}$ (ortalama $\pm \mathrm{sd}$ ) & $233 \pm 93.14$ \\
\hline Başvuru CRP (ortalama $\pm s d$ ) & $12.5 \mathrm{mg} / \mathrm{dL}( \pm 10 \mathrm{mg} / \mathrm{dL})$ \\
\hline Başvuru PCT (ortalama $\pm s d$ ) & $0.71 \mathrm{mg} / \mathrm{dL}(0.05 \mathrm{mg} / \mathrm{dL})$ \\
\hline Başvuru Lökosit (min-max) & $12770 / \mathrm{mm}^{3}\left(200-32150 / \mathrm{mm}^{3}\right)$ \\
\hline
\end{tabular}

\section{Tablo 2. Hastanede gelişen pnömoni tanı anında infeksiyon belirteçleri ve radyolojik bulguları}

$\begin{array}{ll}\text { CRP }(\mathrm{mg} / \mathrm{dL})(\text { ortalama } \pm \mathrm{sd}) & 13.8 \pm 8.5 \\ \mathrm{PCT}(\mu \mathrm{g} / \mathrm{L}) \text { min-max) } & 1.28(0.08-100) \\ \text { CPIS (ortalama } \pm \mathrm{sd}) & 5.0 \pm 1.8 \\ \left.\text { Lökosit (hücre } / \mathrm{mm}^{3}\right) \text { (min-max) } & 13030(1870-66660) \\ \text { Radyoloji }(\mathrm{n}, \%) & \\ \quad \text { Tek taraflı infiltrasyon } & 39(63.0) \\ \quad \text { Çift taraflı infiltrasyon } & 20(32.0) \\ \quad \text { Plevral efüzyon + tek taraflı infiltrasyon } & 3(5.0)\end{array}$

yel etken saptanırken, yirmi bir (\%33.9) hastada birden fazla etken saptanmıstır. Bu yöntem ile sadece bes (\%8.1) hastada etken saptanamamıstır. Etken saptama yöntemi olarak PZR kullanıldığında; yirmi sekiz hastada sadece $A$. baumannii, on dört hastada $A$. baumannii ve $P$. aeruginosa, üc hastada $A$. baumannii ve $S$. maltophilia, bir hastada $A$. baumannii, $P$. aeruginosa ve $S$. maltophilia; yedi hastada sadece $P$. aeruginosa, bir hastada $P$. aeruginosa ve $S$. maltophilia, iki hasta 


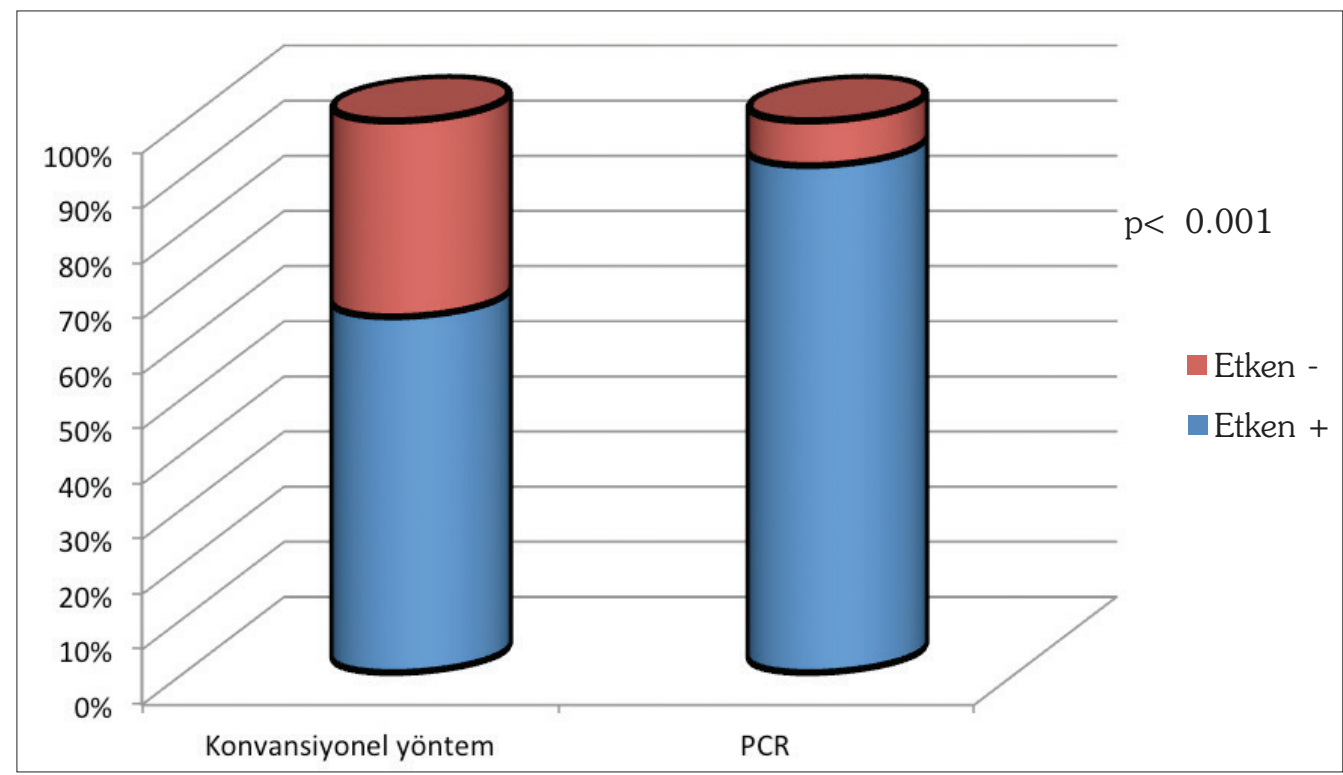

Şekil 1. Konvansiyonel yöntem ve PCR ile etkenlerin saptanma oranları.

$P$. aeruginosa ve $S$. aureus, bir hastada sadece S. maltophilia saptanmıstır.

Konvansiyonel yöntem ile altmıs iki hastanın yirmi sekizinde (\%45.2) bakteriyel etken olarak $A$. baumannii saptanırken, PZR ile altmıs iki hastanın kırk altısında (\%74.2) bakteriyel etken olarak $A$. baumannii saptanmıstır. Etken olarak PZR ile $A$. baumannii saptanma oranının anlamlı derecede yüksek olduğu görülmüștür $(p<0.0001)$. A baumannii saptanan 28 örneğin 27'sinde PZR ile de A. baumannii saptandığ1 izlenmiștir. Konvansiyonel yöntemlerle etken izole edilmeyen on dokuz hastada PZR ile $A$. baumannii saptanmıștır.

Konvansiyonel yöntem ile altmıs iki hastanın on birinde (\%17.7) bakteriyel etken olarak P. aeruginosa saptanırken, PZR ile altmıs iki hastanın yirmi besinde (\%40.3) bakteriyel etken olarak $P$. aeruginosa saptanmıștır. Etken olarak PZR ile $P$. aeruginosa saptama oranının anlamlı derecede yüksek olduğu görülmüstür $(\mathrm{p}<0.0001) . P . a e-$ ruginosa saptanan 11 örneğin 10'unda PZR ile de $P$. aeruginosa saptandığı izlenmiștir. Konvansiyonel yöntemlerle etken izole edilmeyen on bes hastada PZR ile $P$. aeruginosa saptanmıștir.

Konvansiyonel yöntemler ile altmıs iki hastanın ikisinde (\%3.2) etken olarak S. maltophilia üremiștir. Altı hastada PZR ile (\%9.7) etken olarak S. maltophilia saptanmıstır.

S. aureus, konvansiyonel yöntemler ile 1 örnekte pozitif olarak saptanırken, PZR ile 2 örnekte pozitif olarak saptanmıstır.

S. aureus ve S. maltophilia, izole edilen hasta sayısının az olması nedeniyle uyum açısından değerlendirilememiștir.

Konvansiyonel yöntemler ile üretilen $K$. pneumonia ve $C$. striatum etkenleri PZR kitlerinde bulunmadığı için PZR ile bu etkenler saptanamayacağından değerlendirmeye alınamamıștır.

Tablo 3'te ortalama hastanede ve yoğun bakım ünitelerindeki yatıs süreleri belirtilmiștir. Tablo 4'te PZR yöntem ile konvansiyonel yöntemin

Tablo 3. Hastanede ve YBÜ'de ve hastanede yatış süresi, antibiyotik süresi

\begin{tabular}{lc} 
& Ortalama \pm sd \\
\hline YBÜ yatış süresi & $37.0 \pm 44.8$ gün \\
Hastanede yatış süresi & $41.7 \pm 43.7$ gün \\
Ortalama antibiyotik süresi & $26.0 \pm 17.7$ gün \\
Etkene yönelik antibiyotik süresi & $13.5 \pm 17.6$ gün
\end{tabular}


Tablo 4. PCR ile etken saptanıp konvansiyonel yöntemlerle etken saptanan ve saptanmayan hastaların karşılaştırılması

\begin{tabular}{|c|c|c|c|}
\hline \multicolumn{4}{|c|}{ PCR + } \\
\hline & $\begin{array}{c}\text { Konvansiyonel + } \\
n=39\end{array}$ & $\begin{array}{c}\text { Konvansiyonel - } \\
n=18\end{array}$ & p \\
\hline $\begin{array}{l}\text { Cinsiyet }(n, \%) \\
\text { Kadın } \\
\text { Erkek }\end{array}$ & $\begin{array}{l}13(33.3) \\
26(66.7)\end{array}$ & $\begin{array}{c}5(27.7) \\
13(72.3)\end{array}$ & 0.461 \\
\hline Yaş (yıl) & $70.8 \pm 15.2$ & $69.1 \pm 15.7$ & 0.693 \\
\hline Sigara kullanımı $(\mathrm{n}, \%)$ & $14(77.7)$ & $5(45)$ & 0.085 \\
\hline $\begin{array}{l}\text { İmmünsüpresyon }(\mathrm{n}, \%) \\
\text { Var } \\
\text { Yok }\end{array}$ & $\begin{array}{c}7(18) \\
32(82)\end{array}$ & $\begin{array}{c}2(11) \\
16(89)\end{array}$ & 0.408 \\
\hline Mortalite $(n, \%)$ & $30(77)$ & $13(72)$ & 0.471 \\
\hline CPIS* & $5.6 \pm 1.6$ & $4.1 \pm 1.7$ & 0.009 \\
\hline Lökosit $\left(/ \mathrm{mm}^{3}\right)^{*}$ & $16100 \pm 12828$ & $14700 \pm 4705$ & 0.668 \\
\hline $\operatorname{CRP}(\mathrm{mg} / \mathrm{dL})^{*}$ & $15.2 \pm 9.4$ & $11.8 \pm 6.5$ & 0.180 \\
\hline PCT $(\mu \mathrm{g} / \mathrm{L})^{*}$ & $10.7 \pm 19.1$ & $5.0 \pm 12.3$ & 0.257 \\
\hline
\end{tabular}

Tablo 5. Klinik özelliklerin ve örnek alındığı günkü laboratuvar bulgularının mortalite ile ilişkisi

\begin{tabular}{|c|c|c|c|}
\hline & Mortalite (-) $n=17$ & Mortalite (+) $n=45$ & p \\
\hline \multicolumn{4}{|l|}{ Cinsiyet (n,\%) } \\
\hline Kadın & $7(41)$ & $13(29)$ & 0.265 \\
\hline Erkek & $10(59)$ & $32(71)$ & \\
\hline Sigara kullanımı $(n, \%)$ & $7(70)$ & $16(69.5)$ & 0.657 \\
\hline İmmünsüpresyon $(n, \%)$ & $1(5)$ & $10(22)$ & 0.127 \\
\hline Entübasyon (n,\%) & $14(82)$ & $44(98)$ & 0.059 \\
\hline Yaş (yıl) & $61.41 \pm 16.7$ & $72.84 \pm 14.2$ & 0.009 \\
\hline CPIS & $4.1 \pm 1.7$ & $5.3 \pm 1.7$ & 0.048 \\
\hline $\mathrm{PaO}_{2} / \mathrm{FiO}_{2}$ & $286.85 \pm 96$ & $224.95 \pm 91.8$ & 0.042 \\
\hline Lökosit $\left(/ \mathrm{mm}^{3}\right)$ & $14347 \pm 3929$ & $15676 \pm 12188$ & 0.52 \\
\hline CRP $(\mathrm{mg} / \mathrm{dL})$ & $10.42 \pm 5.4$ & $15.04 \pm 9.1$ & 0.018 \\
\hline PCT $(\mu \mathrm{g} / \mathrm{L})$ & $2.74 \pm 7.0$ & $10.75 \pm 19.2$ & 0.022 \\
\hline Hastane yatış günü & $58.9 \pm 60.9$ & $35.1 \pm 33.7$ & 0.055 \\
\hline YBÜ yatış günü & $51.8 \pm 63.8$ & $31.4 \pm 34.4$ & 0.109 \\
\hline
\end{tabular}

karșılaștırılması yapılmıștır. Hem hızlı moleküler yöntemler hem de konvansiyonel yöntemlerle etken izole edilen hastalar ile sadece hızlı moleküler yöntemlerle etken saptanan hastalar arasında mortalite ve laboratuvar değerleri açısından fark saptanmamistır.

Altmıs iki hastanın kırk beșinde (\% 72.6) mortalite izlenmiștir. Mortalite izlenen hastalarda ör- nek alınma anında yas ortalamasının $(p=0.009)$, CPIS skorunun $(p=0.048), \operatorname{CRP}(p=0.018)$ ve PCT (p: 0.022) değerlerinin anlamlı olarak daha yüksek, $\mathrm{PaO}_{2} / \mathrm{FiO}_{2}$ oranının $(\mathrm{p}=0.042)$ anlamlı olarak düșük olduğu saptanmıștır (Tablo 5).

\section{TARTIȘMA}

Yatıs gerektiren toplumda gelișen pnömonilerde mortalite \%5.7-14 arasında iken hastanede gelișen 
pnömonide bu oran \%50'ye kadar c1kmaktadir ${ }^{[8]}$. Hastanede gelișen pnömoniden süphelenildiğinde kültürler alındıktan sonra antimikrobiyal tedavinin bir an önce bașlanması önemlidir. Tedavinin geciktirilmesi veya etken patojene yönelik tedavi verilememesi durumunda mortalite artar. Gec dönemde gelișen pnömonilerde dirençli bakteriler etken olarak saptanmaktadır ${ }^{[1]}$. Pnömonide etken mikroorganizmalarının hızlı bir sekilde saptanması ve uygun antibiyotik tedavisinin hızl bir sekilde bașlanması prognozu olumlu yönde etkileyecek en önemli yaklașımlardır.

Geç dönemde ortaya çkan HGP'lerde gram-negatif basiller en sk izole edilen etkenlerdir. Herkel ve arkadașlarının HGP epidemiyolojisi üzerine yaptığ1 cok merkezli bir calıșmada 201 HGP hastasının 175 'indeyüz yetmis beșinde (\%81.8) gec dönem HGP saptanmıs olup en sık izole edile etkenler sirasi ile $P$. aeruginosa, $K$. pneumonia ve $E$. colidir ${ }^{[3]}$. Ülkemizde 279 VIP epizodunun değerlendirildiği bir çalıșmada VIP etkeni olarak en sik $A$. baumannii (\%37), MRSA (\%27.8) ve $P$. aeruginosa (\%23.2) izole edilmistir ${ }^{[9]}$. Karadeniz Teknik Üniversitesi Tıp Fakültesinde yapılan ve YBÜ'nde infeksiyon etkenlerini değerlendiren calısmada; $P$. aeruginosa \%31.4, A. baumannii \%19.6, MRSA \%15.7, S. maltophilia \%9.8 oranlarında etken olarak belirlenmistir ${ }^{[10]}$. Bizim calıșmamızda konvansiyonel yöntem ile 28 (\%45.2) hastada $A$. baumannii, 11 (\%17.7) hastada $P$. aeruginosa izole edilmiștir.

Son yillarda bakteriyel infeksiyonlarda etken mikroorganizmaların saptanmasında hızlı moleküler yöntemlerin değerlendirildiği calıșmaların sayısında artış gözlenmektedir. Alt solunum yolu infeksiyonları patojenlerinin saptanmasında PZR ve konvansiyonel yöntemlerin kıyaslandığı Aydemir ve arkadașlarının calısmasında; toplumda gelisen pnömoni, KOAH ve bronșektazi alevlenmesi ve akut alt solunum yolu infeksiyonu olan toplam 197 hasta değerlendirilmiștir. Balgam, nazofaringeal sürüntü, BAL örneklerinde konvansiyonel yöntemle ve PZR ile bakteriyel etkenler izole edilmiștir. Kültür ile 62 (\%31.5) hastada en az bir bakteri izole edilirken, PZR ile 125 (\%63.5) hastada (\%32 S. pneumoniae, \%31 H. influenzae) etken saptanmıstır. Sadece bir hastada PZR ve konvansiyonel yöntemlerde farklı mikroorganizma saptanmıștır. Kültür yöntemi altın standart olarak kabul edildiğinde, PZR yönteminin duyarllığı \%96, pozitif prediktif değeri \%95 olarak bulunmustur. Çoklu etken saptamada kültür ve PZR arasında anlamlı fark olup $(p<0.005)$, konvansiyonel yöntem ile iki hastada, PZR ile 47 hastada coklu etken izole edilmiștir ${ }^{[11]}$. Bizim calıșmamızda, PZR yönteminin konvansiyonel yönteme göre duyarlllı̆̆ $\% 97.5$, özgülllüğü \%18 ve pozitif prediktif değeri ise \%68.4 olarak bulunmustur. Konvansiyonel yöntemler ile elde edilen etken patojenler ile PZR ile elde edilen etken patojenlerin uyumlu olması nedeniyle duyarlılık değeri yüksek saptanmıștır.

Ege Üniversitesinde yapılan bașka bir klinik calıșmada, 55 toplumda gelișen pnömoni olgusunun solunum örnekleri konvansiyonel yöntemler ve PZR yöntemi ile değerlendirilmiștir. Konvansiyonel yöntemlerle hastaların \%60'inda bakteriyel etken saptanırken, PZR ile hastaların \%94'ünde etken saptanmıștır ve PZR ile etken saptama oranlarının daha fazla olduğu gözlenmiștir. Konvansiyonel yöntemlerle 12 hastada, PZR ile 24 hastada S. pneumoniae saptanırken; $H$. influenzae konvansiyonel yöntemlerle 11 hastada, PZR ile 17 hastada saptanmıștır ${ }^{[12]}$.

Bizim çalısmamızda ise konvansiyonel yöntem ile 62 hastanın 40'ında (\%64.5) bakteriyel etken saptanırken, PZR ile 62 hastanın 57'sinde (\%91.9) bakteriyel etken saptanmıștır. Konvansiyonel yöntemlerle $A$. baumannii saptanan 28 örneğin 27'sinde PZR ile de A. baumannii saptandığ 1 izlenmiștir. Konvansiyonel yöntemlerle etken izole edilmeyen 19 hastada PZR ile A. baumannii saptanmıștır. Buna karșın konvansiyonel yöntemlerle $P$. aeruginosa saptanan 11 örneğin 10'unda PZR ile de $P$. aeruginosa saptandığı izlenmiștir. Konvansiyonel yöntemlerle etken izole edilmeyen 15 hastada PZR ile $P$. aeruginosa saptanmıstır. Her iki yöntemle saptanan bakteriyel etkenler beraber değerlendirildiğinde, etken saptanması açısından konvansiyonel yöntem ile PZR yönteminin birbiri ile önemli derecede uyumlu olduğu gözlenmiștir. Aynı zamanda konvansiyonel yöntemler ile yedi (\%17.5) hastada, PZR ile 20 (\%35.1) hastada birden fazla etken saptanmıștır.

Calıșmamizda 39 hastada hem konvansiyonel hem PZR ile etken saptanmıs, 18 hastada konvansiyonel yöntemlerle etken saptanmayip sadece 
PZR ile etken saptanmıstır. Herhangi bir yöntemle etken izole edilebilirliği öngörecek parametreleri belirlemek için her iki grup karșılaștırıldığında; konvansiyonel ve PZR yöntemlerle etken saptanan 39 hastada, sadece PZR ile etken saptanan gruba göre, örnek alınma gününde CPIS değerinin daha yüksek olduğu görülmüștür (5.6'ya karșın 4.0, $p=0.68$ ). Buna karșın, her iki grup arasın$\mathrm{da}$, demografik veriler ve örnek alım günündeki klinik, laboratuvar verileri, radyolojik yaygınlık ve mortalite açısından anlamlı bir fark bulunmamıștır.

Calıșmamızda, 62 hastanın 45'inde (\%72.3) mortalite izlenmiștir. Hastaların hepsinin gec dönemde gelișen HGP olması, çoğunun VIP olması, ek hastalık sayılarının fazla olması ve yas ortalamalarının yüksek olması, mortalite oranının fazla olmasının nedeni olarak düșünülmüștür. Hastanede gelișen pnömoni olgularında bakteremi gelișimi, uygunsuz antibiyotik kullanımı, HGP'nin VIP olması, septik sok, yüksek APACHE II veya SAPS II skoru ve ileri yaș (>60 yaș) ile mortalite oranı $\operatorname{artmaktadir}^{[1]}$. Etken olarak izole edilen mikroorganizmalar da HGP'de mortalite ile ilișkili bulunmuștur. Sevinç ve arkadașları, en yüksek mortalite oranının $K$. pneumoniae izole edilen olgularda olduğunu saptamıșlardır[13]. Bir bașka calıșmada A. baumannii'nin neden olduğu HGP'lerde mortalite oranı daha yuiksek bulunmustur ${ }^{[14]}$. Senguil ve arkadașlarının çalıșmasında; A. baumannii'ye bağlı VIP olgularında, erkek cinsiyet, yüksek APACHE II skoru, böbrek yetmezliği ve düsük trombosit sayısı mortalite ile ilișkili bulunmuștur ${ }^{[21]}$.

Bizim calıșmamızda PZR için alınan örnekler $-80^{\circ} \mathrm{C}$ 'de biriktirilerek toplu olarak calıșıldığı için antibiyotik değișikliği yapılamamıs, klinik yansımaları değerlendirilememiștir. Ancak hasta grubumuzda PZR ile elde edilen mikroorganizmalar ve PZR sonuçlarının konvansiyonel yöntemlerle uyumu dikkate alındığı zaman, yakın gelecekte PZR yöntemlerinin HGP hastalarında rutin kullanıma girmesiyle tedavi sonuçlarının olumlu yönde etkilenebileceği düșünülmüștür.

Toplumda gelișen pnömoni etkenlerinin hılı moleküler yöntemler ile saptanması ile ilgili yeterli sayıda calıșma olmasına rağmen, HGP ile ilgili çalıșmalar oldukça kısıtlıdır. Literatürdeki sınırlı sayıdaki çalıșma göz önünde bulundurulduğunda, çok yüksek olmasa da hasta sayımız çalıșmamızın güç- lü yanını yansıtmaktadır. Alınan örneklerin PZR için $-80^{\circ} \mathrm{C}$ 'de saklanarak toplu olarak calıșılması, sonuçların kliniğe yansımalarının değerlendirilememesi önemli bir kisıtlllik nedenidir.

\section{SONUCุ}

Geç dönemde HGP'den sorumlu etkenin izole edilmesinde, hızl moleküler yöntemler ile konvansiyonel yöntemler arasında iyi derecede bir uyum saptanmıștır. Hizlı moleküler yöntemler ile konvansiyonel yöntemlere göre daha fazla sayıda etken patojen izole edilmiștir. Bu durumun tedavi ve klinik sonuçara yansımalarının daha iyi değerlendirilebilmesi için özellikle infeksiyon ve kolonizasyonun da iyi bir sekilde değerlendirildiği daha fazla sayıda çalıșmaya gerek olduğu düșünülmüștür.

Hızlı moleküler yöntemler ve konvansiyonel yöntemlerle etken izole edilen hastalarla sadece hizlı moleküler yöntemler ile etken izole edilen hastalar arasında prognoz açısından fark saptanmamıștır.

Hızlı moleküler yöntemlerin daha yaygın kullanımının; özellikle HGP için hızlı, uygun ve etkin antibiyotik tedavisi sağlayarak tedavi bașarısızlığ1nın ve antibiyotik direncinin azaltılmasına yardımcı olacağını düșünmekteyiz.

Calıșmamızın kısıtlliklarından biri olan PZR yöntemi ile calıșlacak örneklerin toplu çalıșılmak üzere bekletilmesi, üstün olan yöntemin erken dönemde kullanılamamasına yol açıp, mortalite ile ilgili kazanımların elde edilememesine yol acmıs olabilir.

\section{ETIK KURUL ONAYI}

Calıșma için Ege Üniversitesi Tıp Fakültesi Etik Kurulundan onay alındi (Karar no: 145.1/10 Tarih: 26.06.2014).

\section{ÇIKAR ÇATIȘMASI}

Yazarlar bu makale ile ilgili herhangi bir çkar catıșması bildirmemișlerdir.

\section{YAZAR KATKISI}

Anafikir/Planlama: All of authors

Analiz/Yorum: AU, MST, SA

Veri Sağlama: AU, MST, SA

Yazım: AU, MST, SA, HP

Gözden Geçirme ve Düzeltme: All of authors

Onaylama: All of authors 


\section{KAYNAKLAR}

1. Türk Toraks Derneği: Erişkinlerde Hastanede Gelişen Pnömoni Tanı ve Tedavi Uzlaşı Raporu 2018.

2. Kalil AC, Metersky ML, Klompas M, Muscedere J, Sweeney $D A$, Palmer LB. Management of adults with hospital-acquired and ventilator-associated pneumonia: 2016 Clinical Practice Guidelines by the Infectious Diseases Society of America and the American Thoracic Society. Clin Infect Dis 2016;63(5):61-111.

3. Herkel T, Uvizla R, Doubravskaa L, Adamusa M, Gabrhelikb $T$, Sedlakovaet $M-H$, et al. Epidemiology of hospital-acquired pneumonia: Results of a Central European multicenter, prospective, observational study compared with data from the European region. Biomed Pap Med Fac Univ Palacky Olomouc Czech Repub 2016;160(3):448-55.

4. Michael Klompas. Does this patient have ventilator-associated pneumonia? JAMA 2007;297:1583-93.

5. Endimiani A, Hujer KM, Hujer AM, Kurz S, Jacobs MR, Perlin $D S$. Are we ready for novel detection methods to treat respiratory pathogens in hospital-acquired pneumonia? Clin Infect Dis 2011;52:373-83.

6. Barbier F, Andremont A, Wolff M, Bouadma L. Hospital-acquired pneumonia and ventilator-associated pneumonia: recent advances in epidemiology and management. Curr Opin Pulm Med 2013;19:216-28.

7. American Thoracic Society. Hospital-acquired, Ventilator-associated and Healthcare-associated Pneumonia. Am J Respir Crit Care Med 2005;171:388-416.

8. Şen N, Özhan MH (eds). Pnömoni. Türkiye Solunum Araştırmaları Derneği 2017. TÜSAD Eğitim Kitapları Serisi.

9. Erdem I, Ozgultekin A, Inan AS, Dincer E, Turan G, Ceran $N$. Incidence, etiology, and antibiotic resistance patterns of gram-negative microorganisms isolated from patients with ventilator-associated pneumonia in a medical-surgical intensive care unit of a teaching hospital in Istanbul, Turkey (2004-2006). Jpn J Infect Dis 2008;61(5):339-42.
10. Yılmaz G, Caylan R, Ulusoy H, Aydın K, Erciyes N, Köksal $i$. Yoğun bakım ünitesinde izlenen ventilatörle ilişkili pnömonilerin değerlendirilmesi. Yoğun Bakım Dergisi 2004;4(2):131-7.

11. Aydemir O, Aydemir Y, Ozdemir M. The role of multiplex PCR test in identification of bacterial pathogens in lower respiratory tract infections. Pak J Med Sci 2014;30(5):1011-6.

12. Serin DÇ, Pullukçu H, Çiçek C, Sipahi OR, Taşbakan S, Atalay S. Pneumonia Study Group (Yamazhan T, Taşbakan MI, Arda B, Aydemir Ş, Ulusoy S). Bacterial and viral etiology in hospitalized community acquired pneumonia with molecular methods and clinical evaluation. I Infect Dev Ctries 2014;8(6):510-8.

13. Sevinç C, Şahbaz S, Uysal Ü, Kılınç O, Ellidokuz H, itil O ve ark. Hastane kökenli pnömoni olgularında etken dağılımı ve prognoza etkili faktörler. Tüberküloz ve Toraks Dergisi 2007;55(2):153-9.

14. Bergogne-Berezin E. Importance of Acinetobacter spp. In: Bergogne-Berezin E (ed). Acinetobacter Biology and Pathogenesis. Springer, France 2008;s:1-85.

15. Şengül $A$, Şengül $E$, Barış SA, Hayırlıoğlu N. Factors associated with mortality in ventilator associated pneumonia of multidrug resistant Acinetobacter baumannii. Eur Respiratory J 2013;42:P2747.

\section{Yazıșma Adresi/Address for Correspondence}

Uzm. Dr. Ahmet UYSAL

Trakya Üniversitesi Tip Fakültesi Hastanesi,

Göğüs Hastalıkları Kliniği,

Edirne-Türkiye

E-posta: ahmet-bh@hotmail.com 